\title{
New principles of heat recovery of ventilation emissions from multi-apartment buildings (AB)
}

\author{
Gregory Vasilyev ${ }^{1}$, Nikolay Timofeev ${ }^{1}$, Marina Kolesova ${ }^{1, *}$, Igor Yurchenko, \\ Svetlana Marchenkova ${ }^{2,3}$, and Alexander Dmitriev ${ }^{4}$ \\ ${ }^{1}$ JSC INSOLAR-INVEST, Bolshaya Filevskaya str., bldg. 32, Moscow, 121433, Russia \\ ${ }^{2}$ The Department of urban planning policy of Moscow, Nikitsky lane., bldg. 5, 125009, Moscow, \\ Russia \\ ${ }^{3}$ The State University of Land Use Planning, Kazakova str., bldg. 15, 105064, Moscow, Russia \\ ${ }^{4}$ Plekhanov Russian University of Economics, Stremyanny lane 36, Moscow, Russia
}

\begin{abstract}
The article shows results of studies on assessing the effectiveness of new principles for heat recovery of exhaust air in ventilation systems of apartment buildings (AB). Technological solutions are known that provide heat recovery of the exhaust air for heating the supply air of ventilation systems. The efficiency of such solutions can reach $90 \%$, but only in the coldest five-day period of the year with the maximum temperature difference between the exhaust and supply air. At all other times of the heating season, the efficiency of the recuperative heat exchangers decreases as the outside air temperature rises. In the studies presented in the article, a technology was considered that was free from this drawback. It is based on a two-stage heat recovery of the exhaust air: first, recovery for heating the supply air, and then "additional recovery" using heat pumps for the needs of AB hot water supply. The article shows results of assessing the effectiveness of the proposed two-stage heat recovery of exhaust air in various regions of the Russian Federation.
\end{abstract}

\section{Introduction}

Today, air enters apartments through leaks in window assemblies. However, due to the increase in city noise and dustiness of the outside air, it became necessary to use airproof windows, which made it possible to increase the heat transfer resistance of window units significantly due to the use of low-emission glasses and inert gases, which was difficult or even impossible to do with sheet glass glazing. At the same time, the high tightness of modern windows made natural ventilation systems practically ineffective. The comfort of living in apartments has deteriorated: there is high humidity and low air quality, the likelihood of fungal infections of structures increases. [1]

Studies to assess the efficiency of two-stage heat recovery of ventilation emissions from apartment buildings [2] were carried out using the example of the "basic" AB, spaceplanning solutions, the thermal performance and characteristics of which correspond to the modern energy efficiency requirements imposed by the Russian legislation of the Russian

\footnotetext{
* Corresponding author: eco-insolar@mail.ru
} 
Federation and regulatory and technical documents in the field of energy efficiency to the fullest extent possible.

\section{Methods}

During the study, the "basic" AB "moved" to the climatological conditions of 5 cities, representatives of the Russian Federation regions, priority ones, from the point of view of the article authors, for the introduction of heat pump systems for heat and cold supply (HPSHCS). The list of cities-representatives of priority regions is given in Table 1.[3]

Table 1. List of cities-representatives of priority regions and their main climatological characteristics.

\begin{tabular}{|l|l|c|c|c|c|}
\hline № & Region, city & $\begin{array}{c}\text { Temperature } \\
\text { of the coldest } \\
\text { five-day } \\
\text { period, }{ }^{\mathbf{0}} \mathbf{C}\end{array}$ & $\begin{array}{c}\text { Average } \\
\text { temperature } \\
\text { of the heating } \\
\text { period, }{ }^{\mathbf{C}} \text { C }\end{array}$ & $\begin{array}{c}\text { Duration of the } \\
\text { heating period, } \\
\text { days }\end{array}$ & $\begin{array}{c}\text { Absolute } \\
\text { minimum } \\
\text { temperature, } \\
{ }^{\mathbf{0}} \mathbf{C}\end{array}$ \\
\hline 1 & Moscow & -25 & -2.2 & 205 & -43 \\
\hline 2 & St. Petersburg & -24 & -1.3 & 213 & -36 \\
\hline 3 & Sochi & -2 & 6.6 & 94 & -13 \\
\hline 4 & Yaroslavl & -31 & -4 & 221 & -46 \\
\hline 5 & Irkutsk & -41 & -10.9 & 243 & -50 \\
\hline
\end{tabular}

\section{1 "Basic" apartment building}

A 22-storey one-section building designed by PIK-PROJECT LLC in Moscow at 5 Izmailovsky driveway 5, est. 1 was chosen as the "base" $A B$ for the study within the framework of the Renovation of the City Housing Fund program in Moscow. A photograph of the house is shown in Figure 1. The main characteristics and indicators of the "basic" house are shown in Tables 2-3, and the energy loads and specific energy consumption of the house for the climatic conditions of Moscow are shown in Tables 4 and 5.[4]

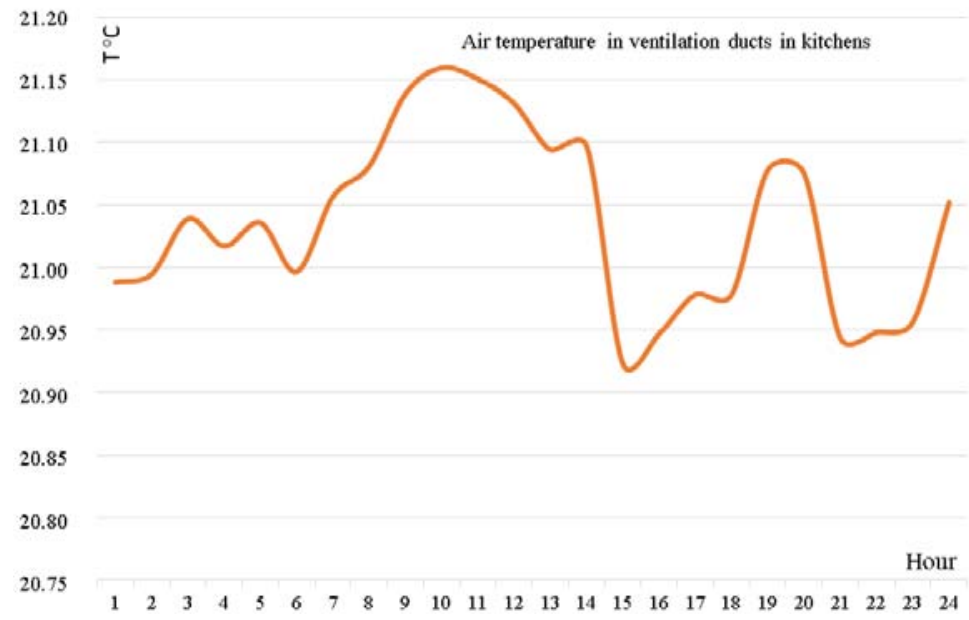

Fig. 1. "Basic" apartment building. 
Table 2. Geometric indicators of the "basic" AB.

\begin{tabular}{|l|c|c|}
\hline \multicolumn{1}{|c|}{ Index } & $\begin{array}{c}\text { Designation and unit } \\
\text { of measure }\end{array}$ & $\begin{array}{c}\text { Estimated design } \\
\text { value }\end{array}$ \\
\hline Total area of the building & A tot, $\mathrm{m}^{2}$ & 14168 \\
\hline Heated area of apartments & A heat, $\mathrm{m}^{2}$ & 9930.0 \\
\hline Living space & Aliv, $\mathrm{m}^{2}$ & 5514.6 \\
\hline Heated volume & Vheat, $\mathrm{m}^{3}$ & 44016.0 \\
\hline Glazing ratio & Kcomp & 0.21 \\
\hline Building compactness index & A ${ }^{\text {tot }} . \mathrm{m}^{2}$ & 0.25 \\
\hline $\begin{array}{l}\text { The total area of the external enclosing } \\
\text { structure of the building, including: }\end{array}$ & Afac & 10841.8 \\
\hline facades & Awall1 & 9488.0 \\
\hline walls (type 1) & Awall 2 & 361.4 \\
\hline walls (type 2) & Awall 3 & 79.4 \\
\hline walls (type 3) & Awall 4 & 4465.4 \\
\hline walls (type 4) & Awall 5 & 46.5 \\
\hline walls (type 5) & Awind.1 & 1881.6 \\
\hline windows and balcony doors of apartments & Awind.3 & 108.7 \\
\hline $\begin{array}{l}\text { windows and stained-glass windows of the first } \\
\text { non-commercial floor }\end{array}$ & Adoor & $23.6 / 116.8$ \\
\hline entrance doors & Acov.2 & 33.0 \\
\hline $\begin{array}{l}\text { coverings of the 1 } 1^{\text {st }} \text { floor (floor of the loggia of } \\
\text { the 2 }\end{array}$ & Atechn.floor & 643.9 \\
\hline "warm" technical floors & Abase1 & 670.3 \\
\hline ceilings above the underground floor & Aoverl.2 & 6.6 \\
\hline Overlapping console & & \\
\hline
\end{tabular}

Table 3. Thermal performance of the "basic" house.

\begin{tabular}{|c|c|c|}
\hline Index & $\begin{array}{c}\text { Units of } \\
\text { measurement }\end{array}$ & Design value \\
\hline $\begin{array}{l}\text { Reduced resistance } \\
\text { heat transfer, including } \\
\text { enclosures: } \\
\text { walls (type 1) } \\
\text { walls (type 2) } \\
\text { walls (type 3) } \\
\text { walls (type 4) } \\
\text { walls (type 5) } \\
\text { windows and balcony doors } \\
\text { windows and stained-glass windows on the } 1^{\text {st }} \text { commercial } \\
\text { floor } \\
\text { windows and balcony doors of staircase and elevator units } \\
\text { entrance doors } \\
\text { coverings of the } 1^{\text {st }} \text { floor (floor of the loggia of the } 2^{\text {nd }} \text { floor) }\end{array}$ & $\begin{array}{l}\left.\text { sq.m. } \cdot{ }^{\circ} \mathrm{C}\right) / \mathrm{W} \\
\left.\text { sq.m. } \cdot{ }^{\circ} \mathrm{C}\right) / \mathrm{W} \\
\left.\text { sq.m. } \cdot{ }^{\circ} \mathrm{C}\right) / \mathrm{W} \\
\left.\text { sq.m. } \cdot{ }^{\circ} \mathrm{C}\right) / \mathrm{W} \\
\left.\text { sq.m. } \cdot{ }^{\circ} \mathrm{C}\right) / \mathrm{W} \\
\left.\text { sq.m. } \cdot{ }^{\circ} \mathrm{C}\right) / \mathrm{W} \\
\left.\text { sq.m. } \cdot{ }^{\circ} \mathrm{C}\right) / \mathrm{W} \\
\left.\text { sq.m. } \cdot{ }^{\circ} \mathrm{C}\right) / \mathrm{W} \\
\left.\text { sq.m. } \cdot{ }^{\circ} \mathrm{C}\right) / \mathrm{W}\end{array}$ & $\begin{array}{c}3.00 \\
3.80 \\
2.05 \\
2.01 / 2.58 \\
2.75 \\
0.81 \\
0.56\end{array}$ \\
\hline
\end{tabular}

Table 4. Estimated energy loads of the "base" house.

\begin{tabular}{|l|c|c|}
\hline \multicolumn{1}{|c|}{ Load type } & $\begin{array}{c}\text { Unit of } \\
\text { measurement }\end{array}$ & $\begin{array}{c}\text { Calculated parameter } \\
\text { value }\end{array}$ \\
\hline Heat load of heating and ventilation & $\mathrm{Gcal} / \mathrm{h}$ & 0.402 \\
\hline $\begin{array}{l}\text { Heat load of ventilation, built-in rooms and /or } \\
\text { car park }\end{array}$ & $\mathrm{Gcal} / \mathrm{h}$ & 0.017 \\
\hline Heat load of hot water supply & $\mathrm{Gcal} / \mathrm{h}$ & 0.486 \\
\hline Electrical load & $\mathrm{kW}$ & 488.6 \\
\hline
\end{tabular}


Table 5. Specific energy consumption.

\begin{tabular}{|l|c|}
\hline \multicolumn{1}{|c|}{ Index } & $\begin{array}{c}\text { Design value, } \\
\mathbf{k W} \mathbf{W}^{*} \mathbf{\mathbf { m } ^ { \mathbf { 2 } }}\end{array}$ \\
\hline $\begin{array}{l}\text { Specific annual consumption of heat energy for heating and } \\
\text { ventilation }\end{array}$ & 54.9 \\
\hline Specific annual consumption of heat energy for hot water supply & 88.6 \\
\hline $\begin{array}{l}\text { Specific annual consumption of electricity for general household } \\
\text { needs }\end{array}$ & 6.0 \\
\hline $\begin{array}{l}\text { Specific annual consumption of heat energy for heating, } \\
\text { ventilation, hot water supply and electric energy for general } \\
\text { household needs }\end{array}$ & 149.5 \\
\hline
\end{tabular}

Analysis of the data on the actual consumption of operated $A B$ showed that the average values of the actual specific annual consumption of heat energy for heating and ventilation of $\mathrm{AB}$ in Moscow can be taken equal to $150 \frac{\mathrm{kWh}}{\mathrm{m}^{2}}$ for residential buildings of the last years of construction in Moscow, to which the considered "basic" AB can be attributed. As a result, during the study, the structure of the specific energy consumption of the "basic" AB for the climatic conditions of Moscow was adopted, presented in Table 6 and Figure 2. [56]

Table 6. The structure of the total specific consumption of energy resources of the "basic" AB in the climatic conditions of Moscow $-248 \mathrm{kWh} / \mathrm{m}^{2}$.

\begin{tabular}{|c|c|}
\hline Specific consumption & $\mathbf{k W h} / \mathbf{m}^{\mathbf{2}}$ \\
\hline of the electric energy for general household needs & 8.0 \\
\hline of the heat energy for heating and ventilation, including & 150.0 \\
ventilation & 95.0 \\
\hline of the heat energy for hot water supply & 90.0 \\
\hline
\end{tabular}

\section{The structure of the total specific consumption of energy resources of the "basic" $A B$ in the climatic conditions of Moscow-248 kWh $/ \mathrm{m}^{2}$}

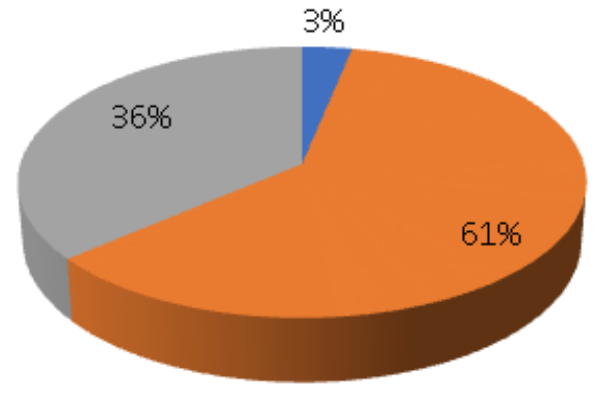

Electric energy for general household needs

Heat energy for heating and ventilation

Heat energy for hot water supply

Fig. 2. The structure of the total specific consumption of energy resources of the "basic" AB in the climatic conditions of Moscow $-248 \mathrm{kWh} / \mathrm{m}^{2}$. 
The purpose of the performed numerical experiments was to assess the efficiency of using two-stage heat recovery from ventilation emissions of $A B$, including heat recovery from the exhaust air for heating the supply air and its subsequent "additional recovery" using HPS. At the same time, "primary" recovery can be carried out both at the apartment level and at the general building level, and additional recovery is carried out at the general building level with the subsequent use of the recovered heat using heat pump equipment for hot water preparation. Excessive recovered heat from ventilation emissions can accumulate in thermal wells. Table 7 shows the average monthly outdoor temperatures in Moscow used in the calculations. [7]

Table 7. Average monthly outdoor temperatures in Moscow according to \{SP 131.13330.2012 Construction climatology $\},{ }^{\circ} \mathrm{C}[8]$.

\begin{tabular}{|c|c|c|c|c|c|c|c|c|c|c|c|}
\hline $\mathbf{X}$ & XI & XII & I & II & III & IV & V & VI & VII & VIII & IX \\
\hline 5.2 & -1.1 & -5.6 & -7.8 & -7.1 & -1.3 & 6.4 & 13.0 & 16.9 & 18.7 & 16.8 & 11.1 \\
\hline
\end{tabular}

On the basis of the average monthly outdoor air temperatures presented in Table 7, the monthly average specific (reduced to the area of apartments) heat loads of the basic house were calculated, which are presented in Figures 3 and 4. The load of hot water supply is averaged over months. October, the first month of the heating period, is taken as the starting point in the diagram. The total specific energy consumption (heat energy without electricity for general household needs) of the basic house without utilization and recovery of secondary energy resources (base case) is $240 \mathrm{kWh} / \mathrm{sq} . \mathrm{m}$ of apartment area per year. [9]

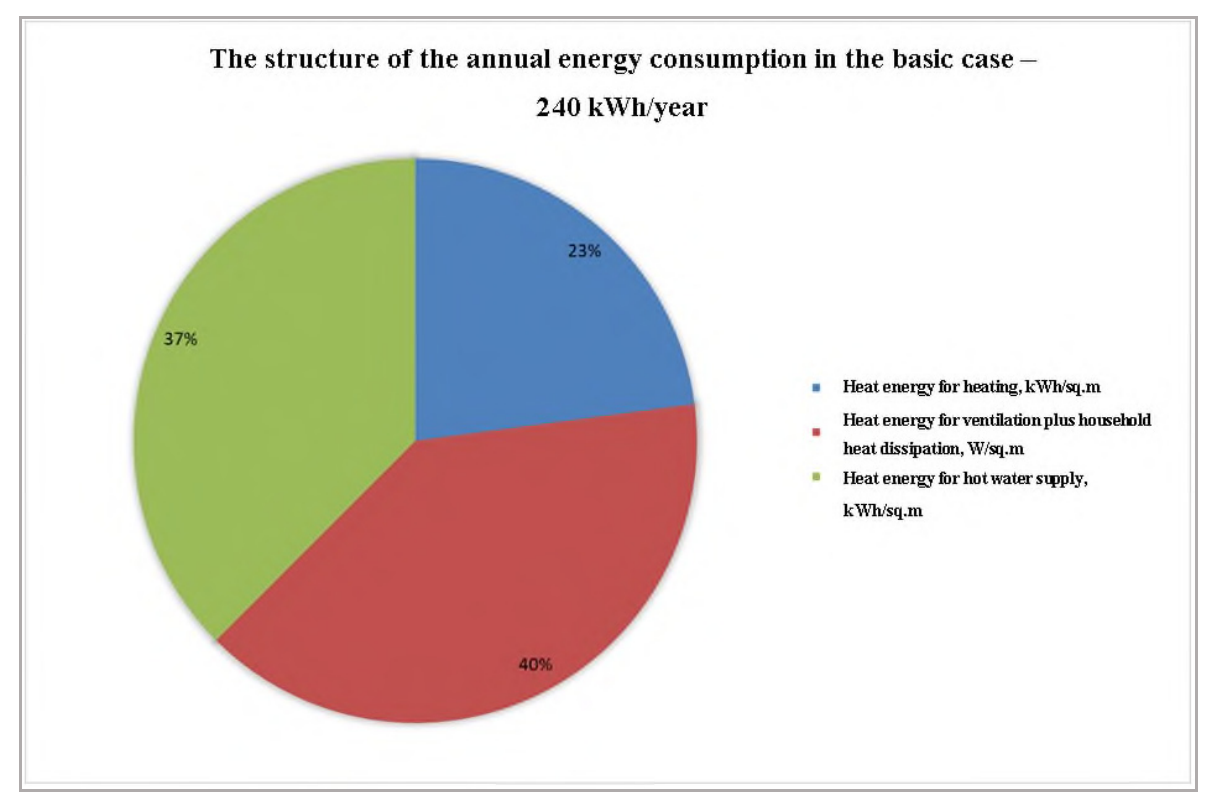

Fig. 3. The structure of the specific annual consumption of energy resources, respectively, in the base case without recuperation and utilization. 


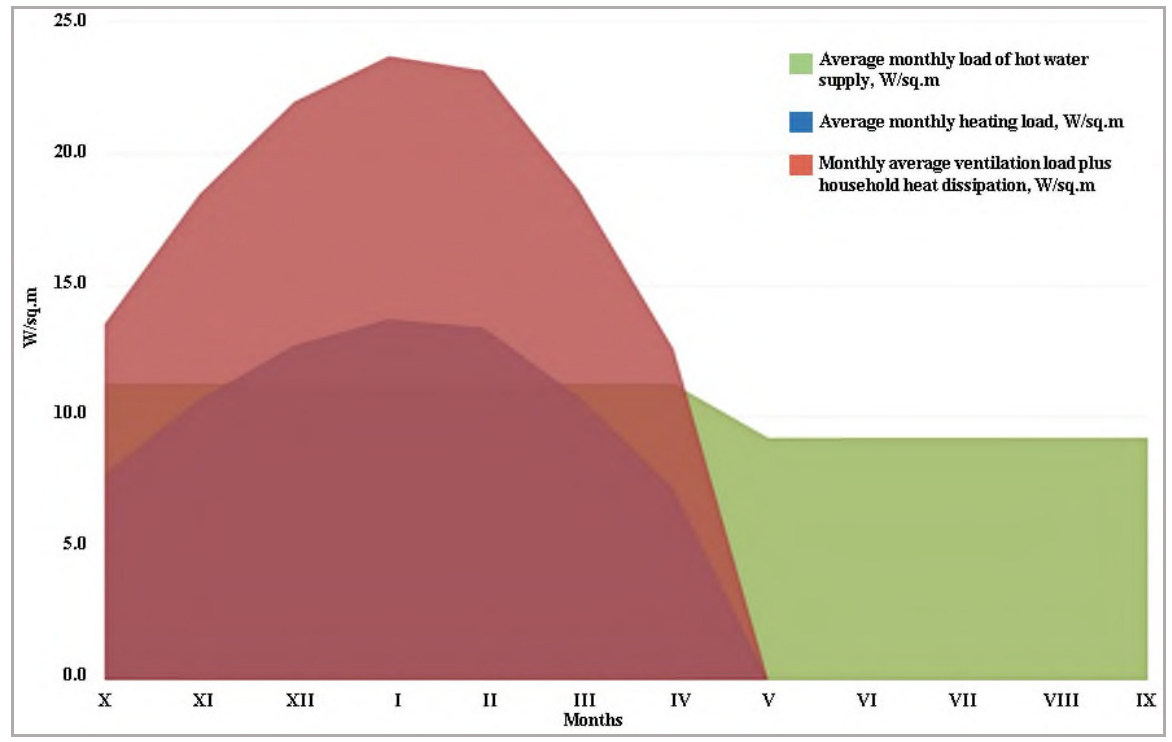

Fig. 4. Monthly average specific (reduced to apartment area) heat loads of basic AB without utilization and recovery of secondary energy resources.

Figure 5 shows the monthly average specific (reduced to apartment area) heat loads of the basic $\mathrm{AB}$ without recuperation, but with the utilization of $50 \%$ of the "waste" heat of ventilation emissions. Utilization of low-potential heat of ventilation emissions is carried out with the help of heat pump equipment HPSHCS, designed for the preparation of hot water. In this case, the heat pump system for hot water supply provides for the accumulation of hot water in storage tanks. In this variant, the total specific energy consumption of a residential building without recuperation, but with utilization of $50 \%$ of the "waste" heat of ventilation emissions for the preparation of hot water, amounted to 174 $\mathrm{kWh} / \mathrm{m}^{2}$ of apartment area per year. At the same time, the calculated specific thermal power of the installed heat pump equipment in this version was $27.8 \mathrm{~W} / \mathrm{sq} . \mathrm{m}$ of the apartments area $[9,10]$.

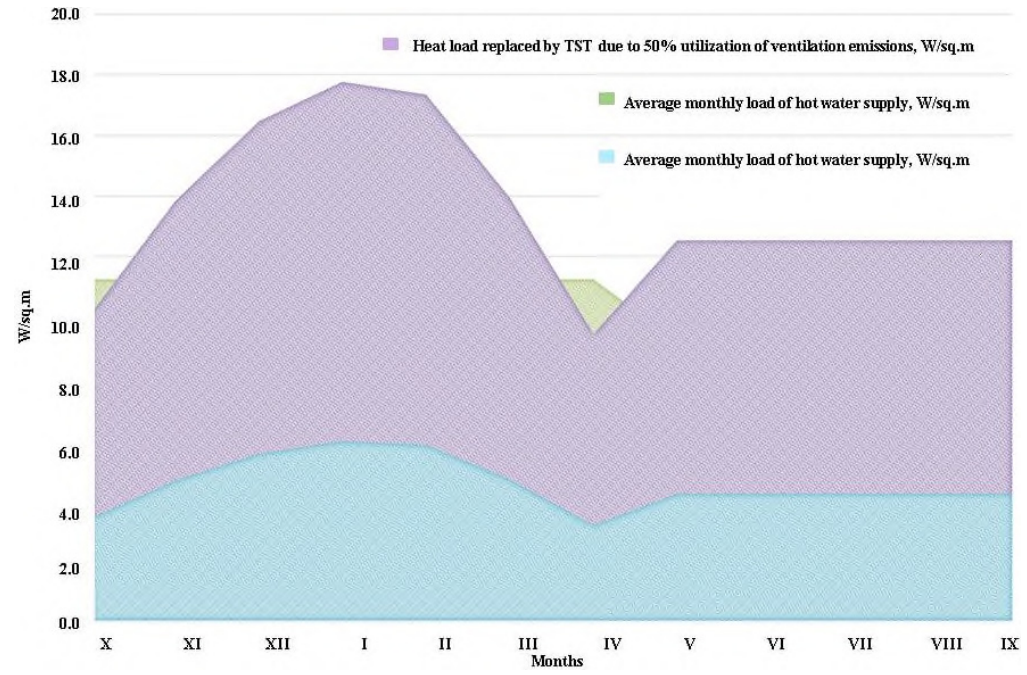

Fig. 5. Monthly average specific (reduced to apartment area) heat loads of a basic apartment building without recuperation, but with utilization of $50 \%$ of the "waste" heat of ventilation emissions. 


\section{Annual energy consumption for heat recovery from ventilation emissions without recuperation $17 \mathrm{kWh} /$ year}

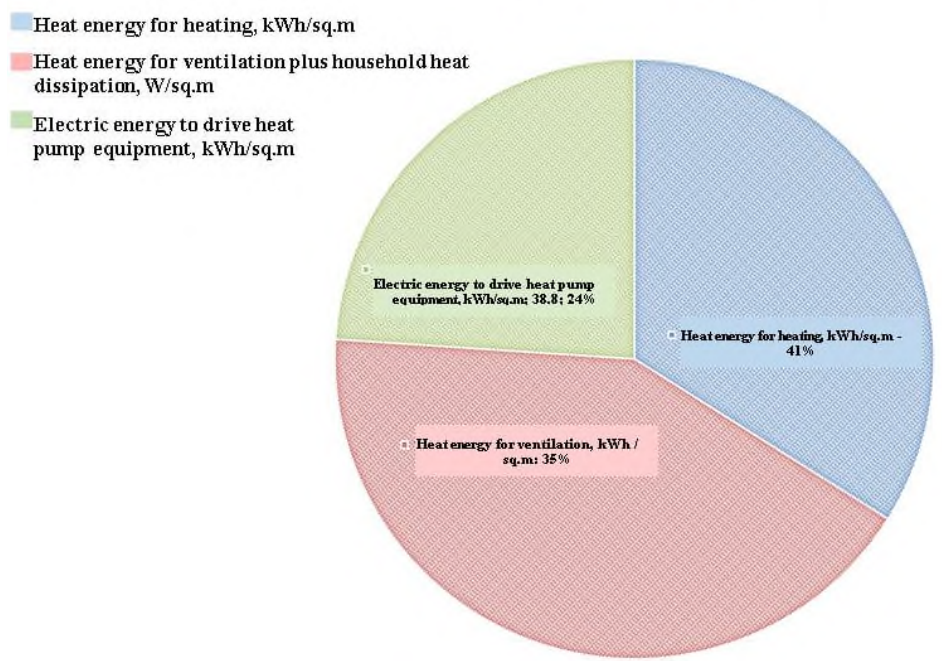

Fig. 6. The structure of the specific annual energy consumption of the basic $A B$ in the option without recuperation, but with the utilization of $50 \%$ of the "waste" heat of ventilation emissions for the needs of hot water supply using heat pump equipment.

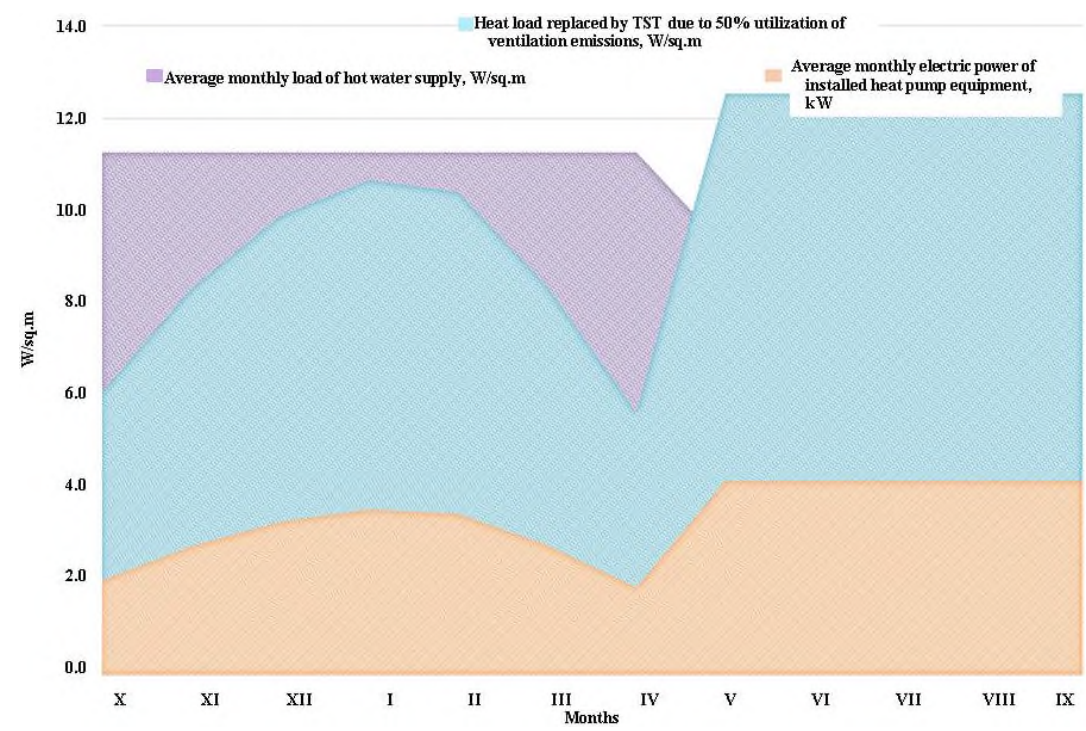

Fig. 7. Monthly average specific (reduced to apartment area) heat loads of the basic AB with $40 \%$ recovery and subsequent additional recovery of $50 \%$ of "waste" heat of ventilation emissions.

Figure 7 shows the monthly average specific (reduced to apartment area) heat loads of the basic $\mathrm{AB}$ with $40 \%$ recovery and subsequent $50 \%$ recovery of the "waste" heat of ventilation emissions. Utilization of low-potential heat of ventilation emissions was carried out using heat pump equipment HPSHCS, designed for hot water preparation. At the same time, the heat pump system for hot water supply provided for the accumulation of hot water in storage tanks. In this variant, the total specific energy consumption of the base AB with $40 \%$ recovery and subsequent additional recovery for hot water preparation of $50 \%$ of the 
"waste" heat of ventilation emissions was already $155 \mathrm{kWh} / \mathrm{sq} . \mathrm{m}$ of the area of apartments per year. At the same time, the calculated specific thermal power of the installed heat pump equipment in this version was 22.3.0 W/sq. $\mathrm{m}$ of the area of apartments [11].

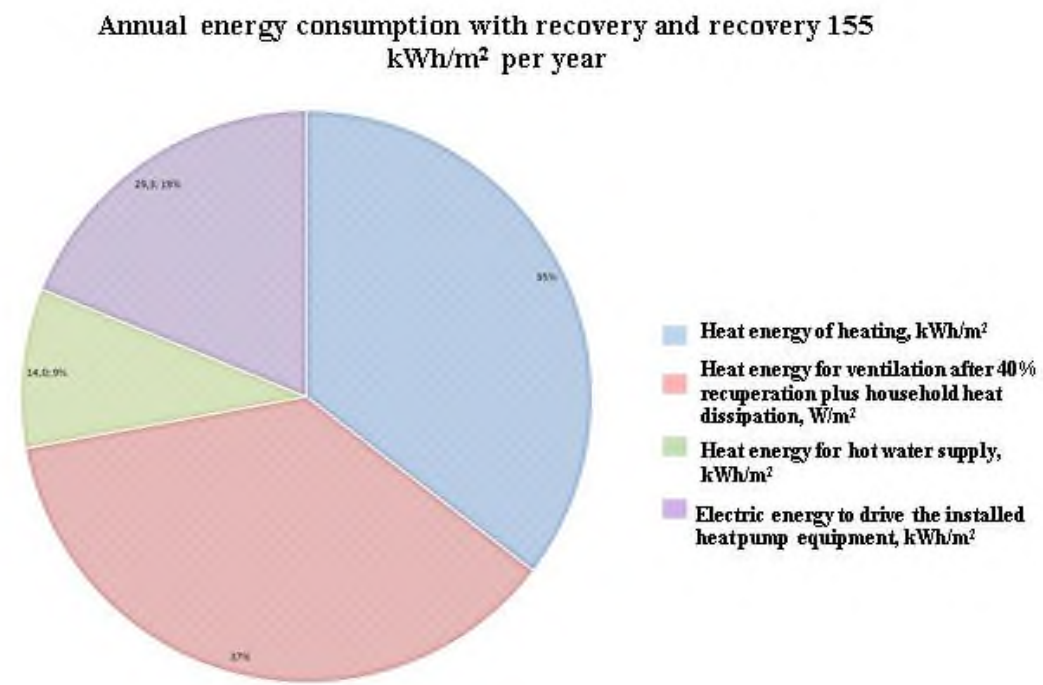

Fig. 8. The structure of the total specific energy consumption of the basic AB with $40 \%$ recovery and subsequent additional recovery of $50 \%$ of the "waste" heat of ventilation emissions.

Similar numerical experiments were carried out for the other four cities of the Russian Federation. The results of numerical experiments to assess the efficiency of the proposed two-stage heat recovery from ventilation emissions $\mathrm{AB}$ for the five cities considered in the studies are shown in Table 8 [12-13].

\section{Results and discussion}

Analysis of the results of numerical experiments presented in Table 8 shows that as a result of $40 \%$ recovery and $50 \%$ utilization for the needs of hot water supply, the "waste" heat of ventilation emissions from the basic $\mathrm{AB}$, it was possible to reduce the total specific energy consumption at $\mathrm{AB}$ significantly in almost all cities, for example, for Moscow conditions from $240 \mathrm{kWh}$ to $155 \mathrm{kWh}$ per square meter of apartment area per year, and for Irkutsk conditions by $40 \%$. Only in Sochi the proposed technology turned out to be less effective, since in this region there is a more efficient source of low-grade heat for heat pumps atmospheric air. [14]

An important result of the calculations is the fact that successive recuperation and additional utilization of waste heat from ventilation emissions $\mathrm{AB}$ for all regions of the Russian Federation, except for Sochi, leads to an increase in the efficiency of using the installed heat capacity of heat pump equipment. So, in the variant without recuperation, but with $50 \%$ heat recovery from ventilation emissions, the calculated thermal power of the required heat pump equipment in Moscow was $27.8 \mathrm{~W} / \mathrm{sq}$. $\mathrm{m}$ of the area of apartments. At the same time, the number of hours of using this power per year was 4179 hours. At the same time, with $40 \%$ recuperation and subsequent $50 \%$ utilization of ventilation emissions for the needs of hot water supply, the calculated thermal power of the required heat pump equipment decreased to $22.3 \mathrm{~W} / \mathrm{sq}$. $\mathrm{m}$ of the area of apartments, and the number of hours 
of using this capacity in a year has already amounted to 5493 hours. As a result, the estimated thermal power of the heat pump equipment decreased by $20 \%$, and the "load" of the equipment in the annual cycle increased by $31 \%$. The highest efficiency of the proposed technology from this point of view was found in St. Petersburg and Yaroslavl - the "load" of heat-equipped equipment in the annual cycle increased by $31 \%$. ... These are very significant indicators that largely determine the technical and economic indicators of heat pump heat supply systems. At the same time, in Yaroslavl, due to the use of the proposed technology of double-stage heat recovery from ventilation emissions $\mathrm{AB}$, the actual cost of heat pump equipment can be halved, and its payback period is reduced by almost $35 \%$. [15]

Table 8. Calculation results for five regions of the Russian Federation.

\begin{tabular}{|c|c|c|c|c|c|c|c|c|c|}
\hline \multirow{2}{*}{ 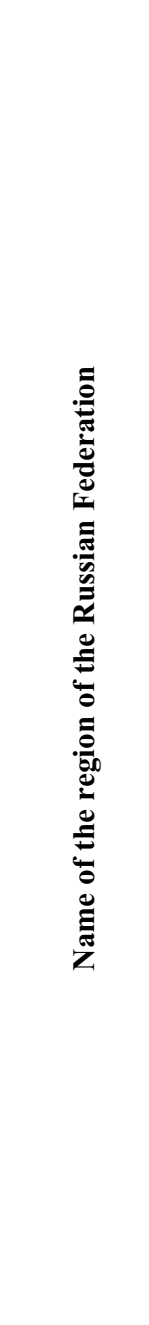 } & \multirow{2}{*}{ 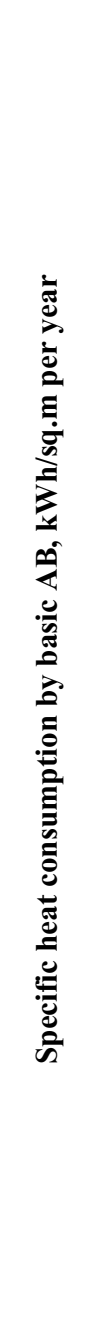 } & \multirow{2}{*}{ 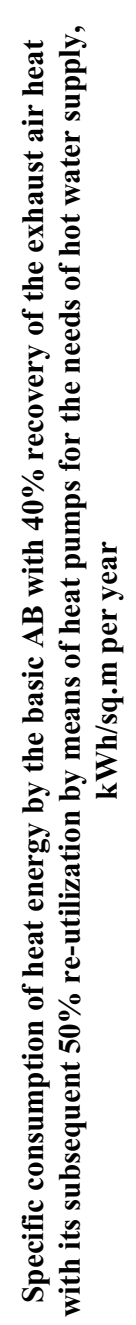 } & \multirow{2}{*}{ 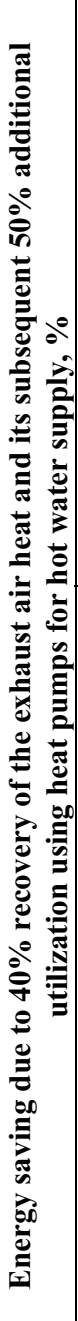 } & \multicolumn{2}{|c|}{ 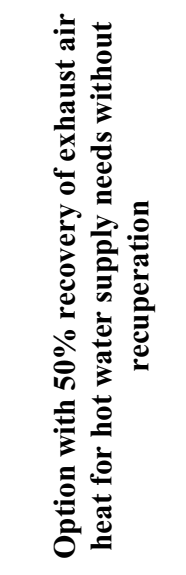 } & \multicolumn{2}{|c|}{ 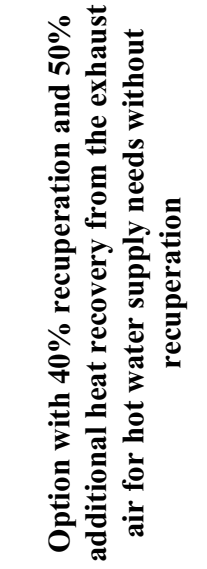 } & \multicolumn{2}{|c|}{ 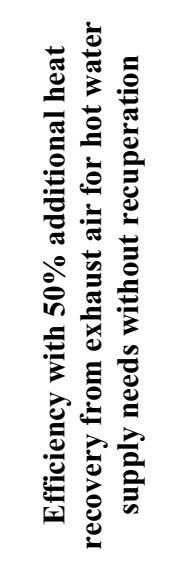 } \\
\hline & & & & 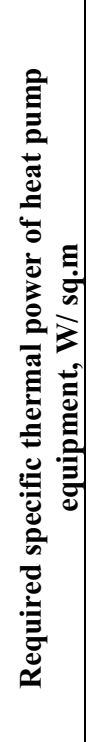 & 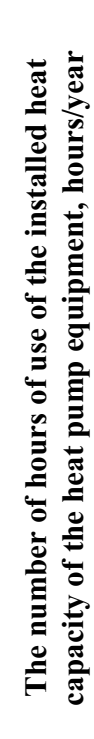 & 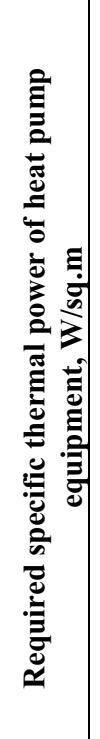 & 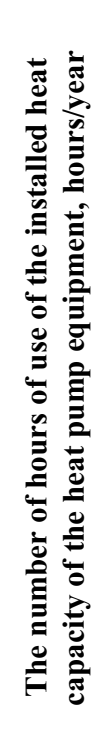 & 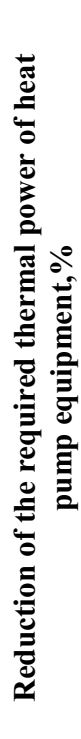 & 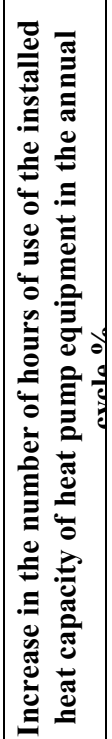 \\
\hline Moscow & & 15 & 35 & 27.8 & & 22.3 & 549 & 2 & 31 \\
\hline $\begin{array}{c}\text { St. } \\
\text { Petersburg }\end{array}$ & 237 & 154 & 35 & 27.3 & 3514 & 16.4 & 4241 & 50 & 40 \\
\hline Sochi & 126,2 & 107.5 & 15 & & & - & & - & - \\
\hline Yaroslavl & 259 & 164 & 37 & 31.4 & 3981 & 18.8 & 4840 & & 35 \\
\hline Irkutsk & 297.1 & 178 & 40 & 37.2 & 3692 & 22.3 & 4500 & 40 & 22 \\
\hline
\end{tabular}


In this work, an analysis and generalization of technological diagrams and technical solutions of natural ventilation systems used in multi-apartment residential buildings was carried out. The systems of natural ventilation of multi-storey buildings of mass development are analyzed, various devices are studied to ensure the inflow of fresh air and the removal (exhaust) from apartments of "exhaust" air, and the influence of various factors on the parameters of operating modes of natural ventilation systems is analyzed. As a result of the analysis, it was found that, as a rule, operated residential buildings do not provide the air exchange necessary for sanitary standards with all the ensuing consequences for the health, efficiency and life expectancy of the country's population. The systems of natural ventilation used today in residential buildings include the following main elements: supply "devices" in the form of windows, vents, interior and sanitary doors with undercuts or transfer grilles for the passage of air to utility rooms, exhaust grilles and the exhaust ducts themselves, which in the most favorable situation, for at least six months, do not provide standard air exchange in residential premises.

As part of the work, experimental studies of the operating modes of existing supply and exhaust natural ventilation devices and the identification of requirements for the developed ventilation valves were carried out. In full-scale conditions, the actual flow rates of outdoor air entering the apartments through the supply valves were studied. Experimental studies of the effectiveness of various designs of supply valves, including valves built into window blocks, have been carried out. Thermal imaging studies of the operating modes of the supply valves have been carried out.

As a result of experimental studies, it was found that supply ventilation valves, both window and wall in the closed position, lead to a slight decrease in the resistance to heat transfer of a window or wall. However, given that the temperature of the room side of a closed window is always lower than that of the inner surface of the wall, the use of a wall damper can be considered preferable, because the same flow of cold air will cool the inner surface of the window to the "dew point" faster than the surface of the wall. At the same time, the use of ventilation valves should be accompanied by an increase in the quality of construction, since, due to the low degree of tightness of the premises, the installed ventilation valves operate in calm weather no more than $25-30 \%$ of their technical capabilities.

For the first time in Russia, the results of comprehensive studies of supply and exhaust valves of natural ventilation systems in multi-storey residential buildings of mass development were obtained. In full-scale and laboratory conditions, the effectiveness of various designs of ventilation valves was investigated, new data on their durability of operation in the climatic conditions of Moscow were obtained. New fundamental technical solutions have been developed for automatic regulation systems for supply and exhaust ventilation valves of natural ventilation systems for multi-apartment buildings of mass development.

Today, in many countries, a variety of supply valves are produced in a variety of designs and materials. This leads to a huge range of prices and creates certain difficulties for the customer when choosing a particular design. On the one hand, it is clear that higher quality materials and greater functionality can be behind a higher price, but it often happens that a higher price is determined only by large dimensions and the use, for example, of more expensive aluminum instead of plastic, and the functionality is worse than that of cheaper designs. In such a situation, it is necessary to determine the selection criteria for supply valves in order to evaluate them by a set of parameters, and not by price indicators alone. 


\section{Conclusions}

Theoretical and experimental studies carried out within the framework of this work revealed that during the year the natural ventilation systems with which already built houses are equipped and, as a rule, new residential buildings continue to be equipped, do not provide the air exchange necessary for sanitary standards with all the ensuing consequences for health, working capacity and life expectancy of the country's population.

The study carried out made it possible to formulate the following basic requirements for the developed ventilation valves and to develop fundamental technical solutions for the system of automatic regulation of supply and exhaust ventilation valves for multi-apartment buildings of mass development. The main result of the work at this stage was the creation of a design and a schematic diagram of control of the supply and exhaust valve of a hygrostat using a servo drive (thermo actuator).

\section{References}

1. G.P. Vasilyev, M.I. Popov, V.F. Gornov et al., Thermal Engineering 66(11), 812-821 (2019)

2. G.P. Vasilyev, V.A. Leskov, N.V. Mitrofanova et al., Energy and Buildings 112, 93100 (2016)

3. G.P. Vasilyev, A.N. Dmitriev, N.A. Timofeev, S.S. Golubev, Energy: Economics, Technology, Ecology 9, 56-61 (2013)

4. G.P. Vasiliev, A.N. Dmitriev, V.F. Gornov et al., Energy Security and Energy Saving 3, 7-11 (2013)

5. G.P. Vasiliev, N.A. Timofeev, M.V. Kolesova, Energetik 8, 35-37 (2012)

6. G.P. Vasiliev, N.A. Timofeev, M.V. Kolesova et al., Energy Safety and Energy Saving 6, 14-21 (2012)

7. G.P. Vasiliev, N.A. Timofeev, V.A. Lichman, S.I. Dubinsky, Energy: Economy, Technology, Ecology 2, 49-52 (2011)

8. SP 131.13330.2012 Construction climatology (2012)

9. G.P. Vasiliev, N.A. Timofeev, AVOK: Ventilation, Heating, Air Conditioning, Heat Supply and Construction Thermophysics 7, 46-51 (2011)

10. G.P. Vasilyev, V.F. Gornov, V.A. Lichman, I.A. Yurchenko, ARPN Journal of Engineering and Applied Sciences 10(15), 6509-6512 (2015)

11. G.P. Vasil'Ev, Thermal Engineering 58(8), 682-690 (2011)

12. G.P. Vasil'ev, Energy Security and Energy Conservation 8, 26 (2011)

13. G.P. Vasil'ev, Thermal Engineering 51(6), 459-467 (2004)

14. O.A. Povarov, O.V. Britvin, A.I. Nikol'skij et al., Russian Journal of Heavy Machinery 8, 5-12 (2002)

15. G.P. Vasilyev, V.A. Leskov, N.V. Mitrofanova et al., Energy and Buildings 112, 93100 (2016)

16. G.P. Vasilyev, M.V. Kolesova, V.F. Gornov, I.A. Yurchenko, MATEC Web of Conferences, 05006 (2016) 